\title{
Methodological approach to determine of small spatial units in a highly complex terrain in atmospheric pollution research: the case of Zasavje region in Slovenia
}

\author{
Andreja Kukec ${ }^{1}$, Marija Z. Boznar ${ }^{2}$, Primoz Mlakar², Bostjan Grasic ${ }^{2}$, Andrej Herakovic ${ }^{3}$, \\ Vesna Zadnik ${ }^{4}$, Lijana Zaletel-Kragelj ${ }^{1}$, Jerneja Farkas ${ }^{1,5}$, Ivan Erzen ${ }^{1,6}$ \\ ${ }^{1}$ Public Health Centre, Faculty of Medicine, University of Ljubljana, Ljubljana, Slovenia; ${ }^{2}$ MEIS Environmental \\ Consulting, Smarje-Sap, Slovenia; ${ }^{3}$ Municipality of Skocjan, Skocjan, Slovenia; ${ }^{4}$ Epidemiology and Cancer \\ Register, Institute of Oncology, Ljubliana, Slovenia; ${ }^{5}$ University Clinic of Respiratory and Allergic Diseases \\ Golnik, Golnik, Slovenia; ${ }^{6}$ National Institute of Public Health of Slovenia, Ljubljana, Slovenia
}

\begin{abstract}
The study of atmospheric air pollution research in complex terrains is challenged by the lack of appropriate methodology supporting the analysis of the spatial relationship between phenomena affected by a multitude of factors. The key is optimal design of a meaningful approach based on small spatial units of observation. The Zasavje region, Slovenia, was chosen as study area with the main objective to investigate in practice the role of such units in a test environment. The process consisted of three steps: modelling of pollution in the atmosphere with dispersion models, transfer of the results to geographical information system software, and then moving on to final determination of the function of small spatial units. A methodology capable of designing useful units for atmospheric air pollution research in highly complex terrains was created, and the results were deemed useful in offering starting points for further research in the field of geospatial health.
\end{abstract}

Keywords: atmospheric air pollution research, highly complex terrain, dispersion models, geographical information systems, small area units, Slovenia.

\section{Introduction}

Numerous studies indicate that the environment has a significant impact on human health (Prüss-Üstun and Corvalan, 2006). Therefore, exploring the spatial relationship between environmental and health phenomena by means of environmental epidemiology, which is the basis for planning evidence-based measures of health protection, is of the utmost importance (Briggs et al., 1996; Elliot et al., 1992, 2000). Application of environmental epidemiology reaches into the past, while the development of modern tools, such as geographical information systems (GIS), is subject to increasing popularity (Jerrett et al., 2005; Beale et al., 2008).

The results of the analysis of the spatial relationship between phenomena can be affected by various factors, including the choice of the spatial unit of observation. The most commonly used units are the existing, administrative, territorial units like municipalities,

Corresponding author:

Ivan Erzen

Public Health Centre, Faculty of Medicine, University of Ljubljana Zaloska 4, Ljubljana, Slovenia

Tel: +3861543 7544; Fax: +38615437541

E-mail: ivan.erzen@mf.uni-lj.si regions or countries (Zadnik and Reich, 2006; Staut, 2008; Wang et al., 2009). However, these spatial units are usually large, resulting in the loss of a great deal of heterogeneity of the data that exist within such an area. This led to the consideration of how to design meaningful, smaller, spatial unit (Stroh et al., 2007; Orru et al., 2009; Eitan et al., 2010; Ocana-Riola, 2010), while the development of GIS tools (Hrvatin and Perko, 2010) made it possible to advance rapidly towards this goal. Although smaller, spatial units can still be determined on an administrative basis (at the level of local communities or settlements), the closest approximation of the actual distribution of observed environmental phenomena in the space would be a more useful basis (Stroh et al., 2007; Eitan et al., 2010; Hrvatin and Perko, 2010). This process lends itself to atmospheric air pollution research by combining elements of physical geography and information about adverse environmental phenomena. However, the design of small spatial units for the study of the effects of atmospheric air pollution on health on the basis of the air dispersion of pollutants can be very difficult in the case of a complex terrain.

We aimed to design small spatial units in a test area, and examine their usefulness in practice, as this would facilitate the preparation of an appropriate methodolo- 
gy for the optimal design of such units of a very complex terrain. The ultimate goal was to develop this methodology for the analysis of the relationship between environmental phenomena and health status of the population. The study is a part of larger project, performed at the Chair of Public Health, Faculty of Medicine, University of Ljubljana between October 2010 and September 2012, in collaboration with environmental and health experts (Kukec et al., 2012).

\section{Materials and methods}

\section{Area and time of observations}

The area of Zasavje region $\left(263.5 \mathrm{~km}^{2}\right)$, consisting of the three municipalities Zagorje, Trbovlje and

Box 1. Major sources of air pollution in the Zasavje region, Slovenia.

Zagorje municipality
Construction material plant; district heating plant; electri-
cal components plant; timber industry plant; quarries (loca-
tions A and B).
Trbovlje municipality
Cement plant; district heating plant; foundry; thermal
power plant; quarries (locations A and B).
Hrastnik municipality
Centre for waste management; chemical plant; district
heating plant; glassworks; moulds plant; quarry.

Hrastnik in the central part of Slovenia was chosen for observation covering a 1-year period between January 1, 2011 and December 31, 2011. The Zasavje terrain is defined by the narrow valley of the Sava River and its three side valleys (Fig. 1) and its principal characteristic is that it is geographically highly complex.

Many different kinds of heavy industry (cement, glass, chemicals, etc.), among them one of the biggest thermal power plants in Slovenia (Box 1), are active in Zasavje and the region is considered one of the most polluted regions in the country (Segula et al., 2012). The Slovenian Environment Agency (SEA) mentions 18 major sources of air pollution, which are obligated to have the Integrated Pollution Prevention and Control (IPPC) permition according to the Directive 2008/1/EC (EC, 2008a) for their operation (SEA, 2012), are located in the Zasavje region, six in each municipality (Fig. 1). Out of them, three (a cement plant, a thermal power plant and a glassworks) are sufficiently big polluters to be obligated estimating their impact on the atmospheric air pollution according to existing, legal acts (Government of the Republic of Slovenia, 2007).

\section{Methodology to determine of small spatial units}

The set of data used in this study is first presented followed by modelling of local air pollution. The whole process involving the spatial units consisted of the following two steps:

(i) modelling of pollution in the atmosphere with dispersion models; and

(ii) determination of small, spatial units.
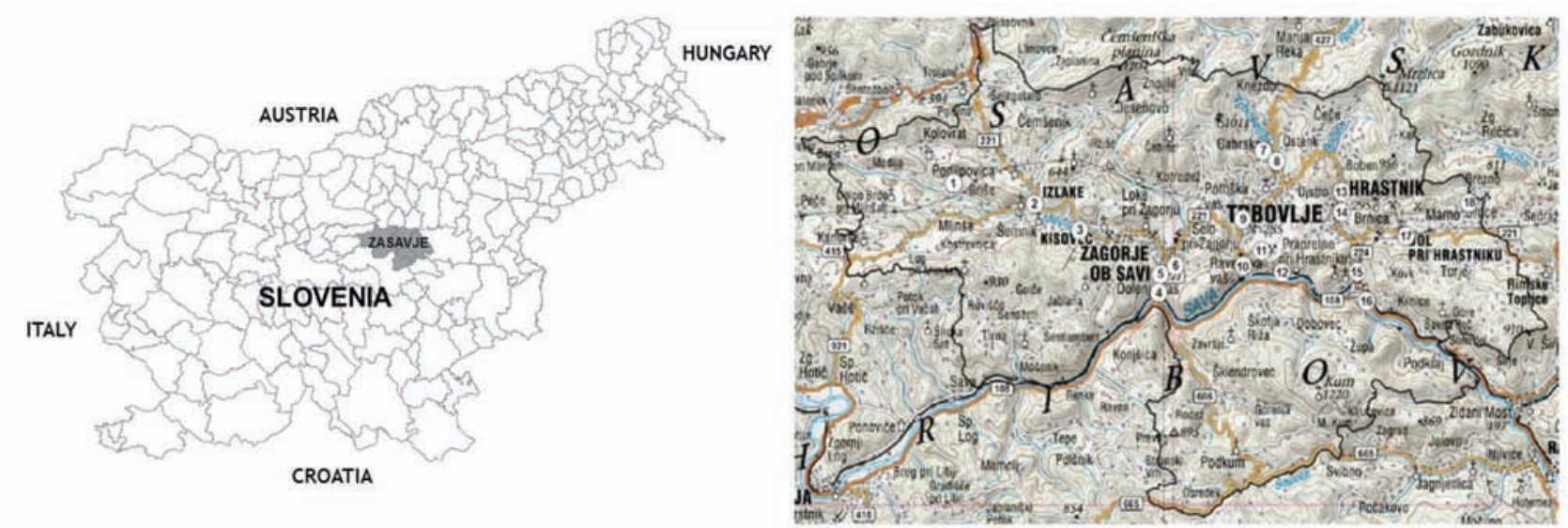

\footnotetext{
1 - The Zagorje quarry, location A

2 - Electrical components plant

3 - The Zagorje quarry, location B

4 - Construction materials plant

5 - Timber industry

6 - Zagorje district heating plant
}

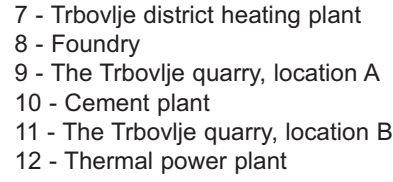

7 - Trbovlje district heating plant

8 - Foundry

9 - The Trbovlje quarry, location A

10 - Cement plant

11 - The Trbovlje quarry, location B

12 - Thermal power plant

13 - The Hrastnik quarry

14 - The Hrastnik district heating plant

15 - Glassworks

16 - Chemical plant

17 - Moulds plant

18 - Waste management centre

Fig. 1. Location of the Zasavje region in Slovenia with detailed map showing the location of potential, major air polluters. 
Modelling of pollution in the atmosphere with dispersion models

\section{Input data}

The data used for modelling are presented below and summarised in Table 1. First, the following preprocessing was done:

(i) Geographical data - the size of the area of modelling was $20 \times 20 \mathrm{~km}$ with a height of $6 \mathrm{~km}$. It was divided into $100 \times 100$ cells $(200 \times 200 \mathrm{~m})$ in the horizontal direction. Ground layer height of the atmosphere, where the Slovenian Decree on ambient air quality is applicable (Government of the Republic of Slovenia, 2011), was $10 \mathrm{~m}$. The dimensions of the ground level cells were thus 200 $\times 200 \times 10 \mathrm{~m}$. A digital elevation model was expressed in altitude in meters, while land cover was expressed in categories (e.g. settlement, grassy area, woody area, etc.). Usually, both parameters are given in different resolutions and must therefore be transformed into a common desired resolution before use in the dispersion models.

(ii) Data on emissions from point sources - the nominal emissions at full capacity of devices were calculated on the basis of the pollutant concentration (in $\mathrm{mg} / \mathrm{m}^{3}$ ), temperature (in $\mathrm{K}$ ) and flow (in $\mathrm{m}^{3} / \mathrm{h}$ ) of released gases. The stack height and exhaust diameter was also considered.

(iii) Data on emissions due to traffic and local individual heating devices - the flat, half-hourly quantity of emissions in tons from the whole, annual traffic emissions for the region was estimated without considering the daily and weekly cycles. However, the spatial density was taken into account. The emissions at the different sections of the road network were weighted according to counters along roads. The same approach was taken with regard to the air pollution due to emissions from local individual heating devices, without considering the seasonal cycles. The emissions in the different parts of the region were weighted according to the size of settlements. The whole region was divided into several small geographical units representing groups of houses where there was no piped hot water or similar heating system. The actual number of people living in each group of houses was taken as proportional factor.

(iv) Data on long-range transboundary air pollution estimates of hourly concentrations in $\mathrm{mg} / \mathrm{m}^{3}$ (cell dimensions $12 \times 12 \mathrm{~km}$ ) were used.

(v) Meteorological data - these data were estimated by the use of the meteorological pre-processor

Table 1. Input data in the process of modelling of the dispersion of pollution in the atmosphere with dispersion models.

\begin{tabular}{|c|c|c|c|}
\hline Type of data & Characteristics of data & Source of data & Notes \\
\hline Geographical data & $\begin{array}{l}\text { Land cover; } \\
\text { digital model of terrain heights }\end{array}$ & $\begin{array}{l}\text { EIONET'a }^{a}, 2000 \\
\text { SMARS }^{\mathrm{b}}, 2012\end{array}$ & - \\
\hline $\begin{array}{l}\text { Data on emissions from point } \\
\text { sources }\end{array}$ & $\begin{array}{l}\text { Particulate matter }\left(\mathrm{PM}_{10}\right) \text {, } \\
\text { sulphur dioxide }\left(\mathrm{SO}_{2}\right) \text { and } \\
\text { nitrogen dioxide }\left(\mathrm{NO}_{2}\right)\end{array}$ & $\begin{array}{l}\text { Sources of air pollution } \\
\text { in the region }(\mathrm{n}=18)\end{array}$ & $\begin{array}{l}\text { Nominal emissions at full } \\
\text { capacity of devices }^{c}\end{array}$ \\
\hline $\begin{array}{l}\text { Data on emissions due to } \\
\text { traffic and local individual } \\
\text { heating devices }\end{array}$ & $\begin{array}{l}\text { Particulate matter }\left(\mathrm{PM}_{10}\right) \text {, } \\
\text { sulphur dioxide }\left(\mathrm{SO}_{2}\right) \text { and } \\
\text { nitrogen dioxide }\left(\mathrm{NO}_{2}\right)\end{array}$ & $\begin{array}{l}\text { ENERGIS Institute } \\
\text { (Cerkvenik et al., 2007) }\end{array}$ & $\begin{array}{l}\text { Estimated yearly quantity } \\
\text { of emissions }\end{array}$ \\
\hline $\begin{array}{l}\text { Data on long-range } \\
\text { transboundary air pollution }\end{array}$ & $\begin{array}{l}\text { Particulate matter }\left(\mathrm{PM}_{10}\right) \text {, } \\
\text { sulphur dioxide }\left(\mathrm{SO}_{2}\right) \text { and } \\
\text { nitrogen dioxide }\left(\mathrm{NO}_{2}\right)\end{array}$ & $\begin{array}{l}\text { QualeAria operational } \\
\text { forecasts of air pollution } \\
\text { (QualeAria, 2012) }\end{array}$ & - \\
\hline \multirow[t]{2}{*}{ Meteorological data } & $\begin{array}{l}\text { Ground level data from meteorological } \\
\text { stations: wind speed and direction at } 10 \\
\text { m; temperature; relative humidity; and } \\
\text { global solar radiation }\end{array}$ & $\begin{array}{l}\text { Slovenian Environment } \\
\text { Agency (SEA) and Trbovlje } \\
\text { Thermal power plant }\end{array}$ & $\begin{array}{l}\text { Data available at precise } \\
\text { locations }\end{array}$ \\
\hline & $\begin{array}{l}\text { Vertical meteorological } \\
\text { profiles }\end{array}$ & $\begin{array}{l}\text { MEIS Environmental } \\
\text { Consulting; Boznar et al., } \\
\text { 2012; WRF model, } 2012\end{array}$ & $\begin{array}{l}\text { Variables from forecast } \\
\text { regarding spatial resolution } \\
\text { of } 4 \mathrm{~km} \text { and temporal } \\
\text { resolution of } 30 \mathrm{~min}\end{array}$ \\
\hline
\end{tabular}

${ }^{a}$ European Environment Information and Observation Network; 'burveying and Mapping Authority of the Republic of Slovenia; 'Data available for five polluting plants in the region (cement, thermal power, glassworks, construction materials and district heating in Zagorje); ${ }^{\mathrm{d}}$ Weather Research and Forecasting. 
"SurfPro" and 3-dimensional (3-D) mass consistent model "Swift" for winds (Desiato et al., 1998); an approximation of the 3-D fields of wind, temperature and turbulence was calculated with a horizontal resolution of $200 \mathrm{~m}$ a temporal resolution of half an hour.

\section{Local air pollution modelling}

The numerical Lagrangian particle model "SPRAY" with the Monte Carlo simulation was applied for simulate the atmospheric pollutants dispersion (Tinarelli et al., 2000). An example of 3-D particle dispersion from the chimney of the thermal power plant by using this model is presented in Fig. 2. The modelling results were expressed as half-hourly concentrations in each cell (MEIS Environmental Consulting, 2012). Finally, the average summer and winter modelled concentrations of particulate matter $\left(\mathrm{PM}_{10}\right)$, the average annual modelled concentrations for sulphur dioxide $\left(\mathrm{SO}_{2}\right)$ and nitrogen dioxide $\left(\mathrm{NO}_{2}\right)$ were calculated. Levels of air pollution were shown using maps with the levels of pollution presented in colour with a continuous colour scale.

\section{Determination of small, spatial units}

ArcGIS was used (ESRI, 2010) for the process with the following data as input:

(i) digital maps of administrative units according to the Surveying and Mapping Authority of the Republic of Slovenia (SMARS) showing settlements and local communities; and

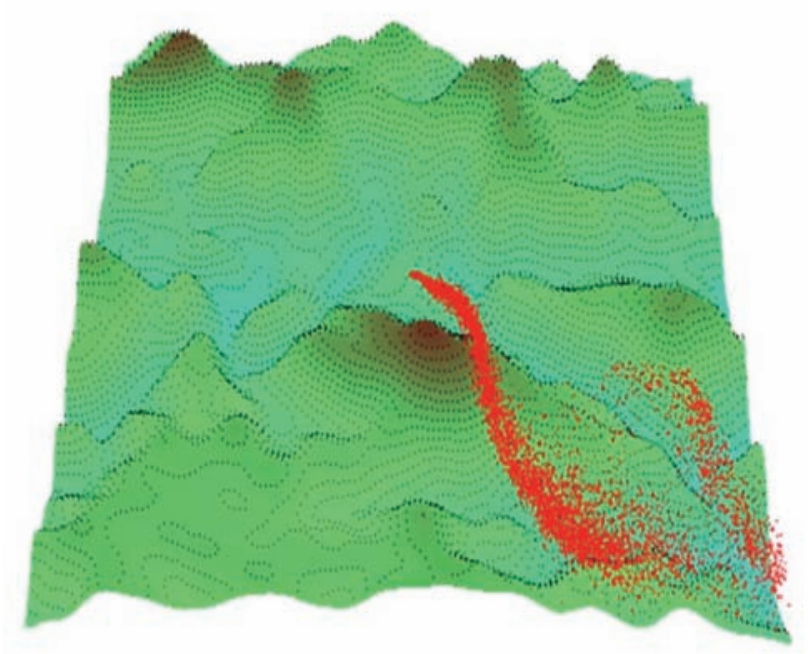

Fig. 2. Example of 3-D particle dispersion of the chimney plume from a thermal power plant (Created by the numerical Lagrangian particle model SPRAY). (ii) air pollution dispersion modelling results transferred to the ArcGIS software (the original continuous values were grouped into five groups as follows: (i) negligible level of air pollution; (ii) low level of air pollution; (iii) moderate level of air pollution; (iv) noticeable level of air pollution but not exceeding the limit; and (v) the level of pollution exceeding the limit) before use. This resulted in a layer in which the smallest unit was a cell of the size $200 \times 200 \mathrm{~m}$.

The process itself consisted of two phases, at the end of which the size of the spatial units was still defined by the size of settlements and/or local communities. It started with the loading of various basic layers to the ArcGIS software. These layers were being added in the following order:

(i) the layer of digital maps with boundaries of local communities;

(ii) the layer of digital maps with boundaries of settlements; and

(iii) the layer of air pollution estimates obtained by the dispersion modelling.

In the second phase, the spatial units obtained at the end of the first phase were inspected for homogeneity of air pollution. If in the individual unit the situation pollution-wise was fairly homogeneous, the unit was kept at the same shape as it was at the end of the first phase of the process. On the contrary, if the situation was not homogeneous, new subunits within such a unit were defined on the basis of air pollution. Thus, at this step, the final set of small, spatial units based on combination of different administrative spatial units and air pollution dispersion modelling results was obtained. For each pollutant, a special model of small, spatial units was determined.

\section{Results}

The results of the estimation of the dispersion of air pollution with dispersion models for average concentrations of $\mathrm{PM}_{10}, \mathrm{SO}_{2}$ and $\mathrm{NO}_{2}$ are shown in Fig. 3. For $\mathrm{PM}_{10}$, two average concentrations are shown: one for the summer (Fig. 3a); the other for the winter (Fig. 3b). For $\mathrm{SO}_{2}$ (Fig. 3c) and $\mathrm{NO}_{2}$ (Fig. 3d) the average annual concentrations for each is shown. In general, the results for $\mathrm{PM}_{10}$ and $\mathrm{NO}_{2}$ show that the maximum level of pollution is dispersed by the prevailing winds from the biggest air pollution source in the direction of the three side-valleys of the Zasavje. The pollution in these three closed valleys also persists longer than it would in a flat area with better ventilation. On the other hand, the level of $\mathrm{SO}_{2}$ does not exceed the per- 


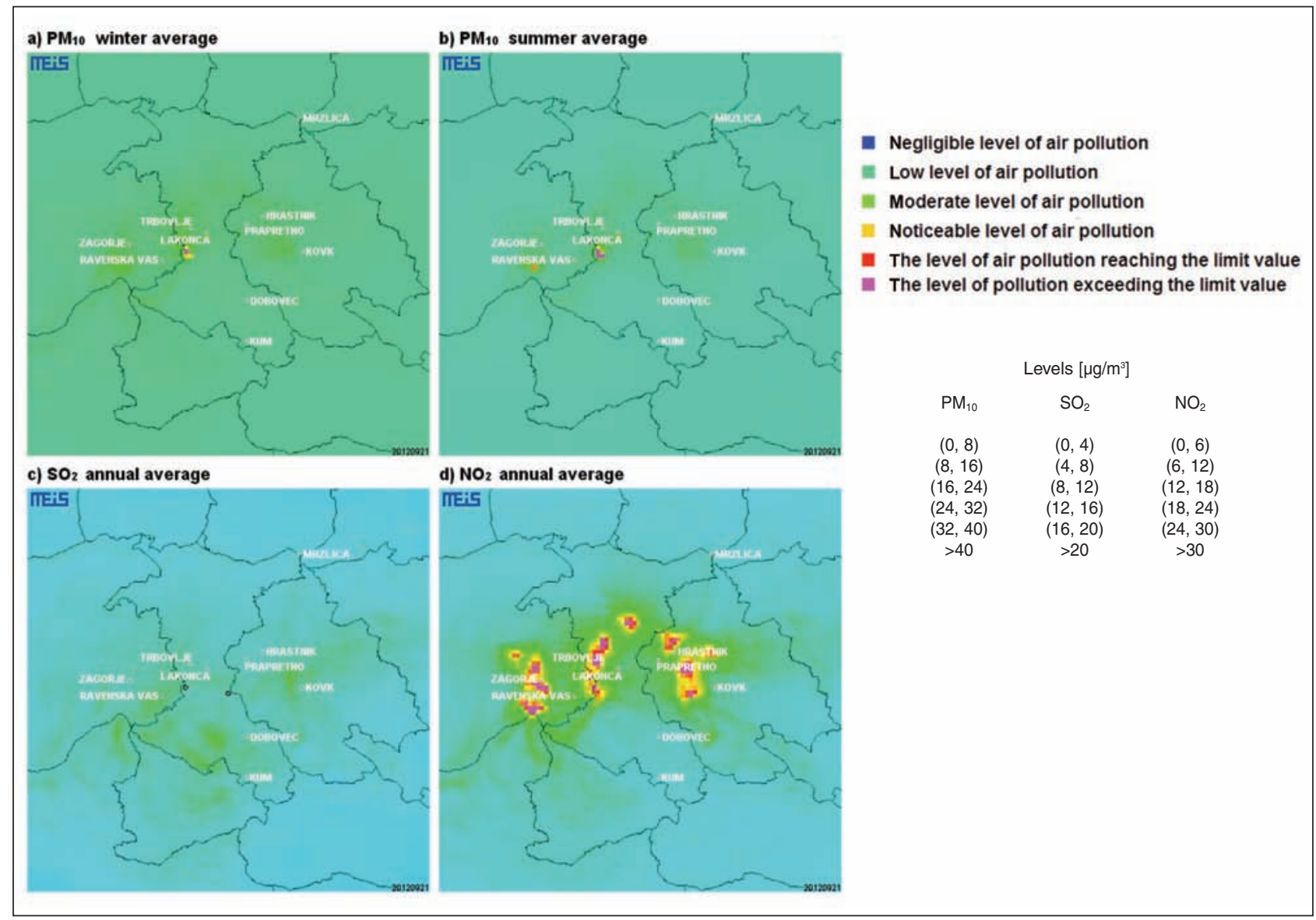

Fig. 3. Estimated dispersion of air pollution in the Zasavje region for the year 2011 with dispersion models for winter and summer average for $\mathrm{PM}_{10}$ and annual averages for $\mathrm{SO}_{2}$ and $\mathrm{NO}_{2}$.

mitted limit of pollution in these valleys. This is due to the low levels of concentration of this pollutant and the dispersion of pollution above the temperature inversion layer. Additionally, the pollution does not extend significantly in the direction of the three sidevalleys.

Fig. 4 shows the results of determination of small spatial units at the end of the first phase of the process. Two average concentrations for $\mathrm{PM}_{10}$, summer (Fig. 4a) and winter (Fig. 4b), annual average $\mathrm{SO}_{2}$ (Fig. 4c) and annual average $\mathrm{NO}_{2}$ (Fig. $4 \mathrm{~d}$ ).

The results of the determination of small spatial units based on the average concentrations of observed pollutants are shown in Fig. 5. Four models of small spatial units were determined. Two models for $\mathrm{PM}_{10}$ : a model with 149 small spatial units for the winter average of $\mathrm{PM}_{10}$ concentrations (Fig. 5a) and a model with 116 small spatial units for the summer average of $\mathrm{PM}_{10}$ concentrations (Fig. 5b). For the annual average of $\mathrm{SO}_{2}$ concentrations, a model with 150 small spatial units (Fig. 5c) and for the annual average of $\mathrm{NO}_{2}$ concentrations, a model with 115 small spatial units (Fig. $5 \mathrm{~d})$ were determined.

\section{Discussion}

Based on the results of our study it can be concluded that the presented methodology for designing small spatial units suits the study of the relationship between environmental phenomena and health status of the population in areas with a very complex terrain. However, the idea of designing spatial units on the basis of approximation of the actual distribution of the observed environmental phenomena is not new. In the review paper of Jerrett et al. (2005) the use of dispersion models with emission and meteorological data as input parameters was recommended for defining small spatial units almost 10 years ago. A similar methodology was also used in several other studies (Stroh et al., 2007; Orru et al., 2009; Eitan et al., 2010). However, all of these studies were performed on a more or less flat terrain. Consequently, the problem of application of this methodology to a very complex terrain remained open. Our study tried to address this important issue.

This study has some potential limitations. Firstly, emission data for all industrial sources of air pollution 

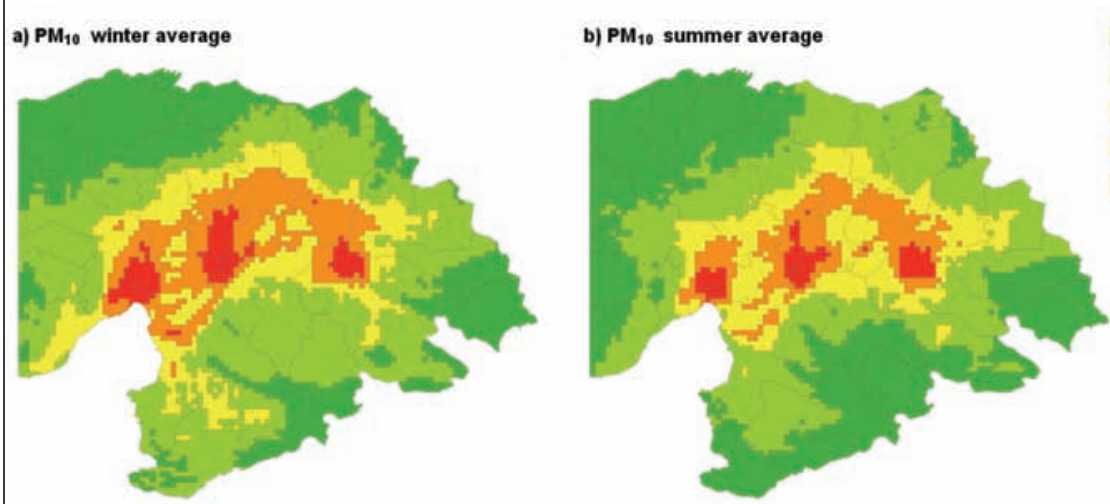

Negligible level of air pollution

Low level of air pollution

Moderate level of air pollution

Noticeable level of air pollution

- The level of pollution exceeding the limit value

c) $\mathrm{SO}_{2}$ annual average

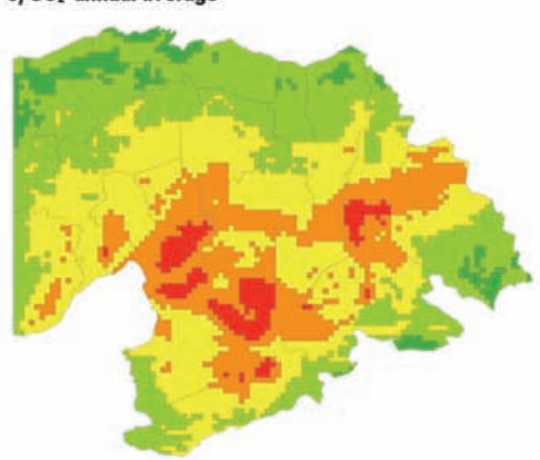

d) $\mathrm{NO}_{2}$ annual average

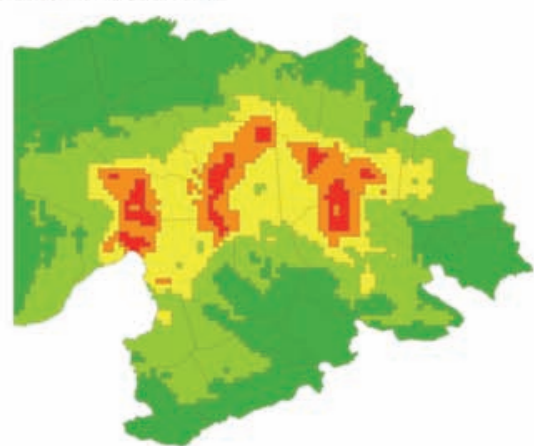

Levels $\left[\mu \mathrm{g} / \mathrm{m}^{3}\right]$

$\begin{array}{lll}\mathrm{PM}_{10} & \mathrm{SO}_{2} & \mathrm{NO}_{2}\end{array}$

$(0,8) \quad(0,4)-(0,6)$

$(8,16) \quad(4,8) \quad(6,12)$

$(16,24) \quad(8,12) \quad(12,18)$

$(24,40) \quad(12,20) \quad(18,30)$

Fig. 4. Small, spatial units for the year 2011 at the end of the first phase of the process as determined separately for winter and summer average for $\mathrm{PM}_{10}$ and annual averages for $\mathrm{SO}_{2}$ and $\mathrm{NO}_{2}$.
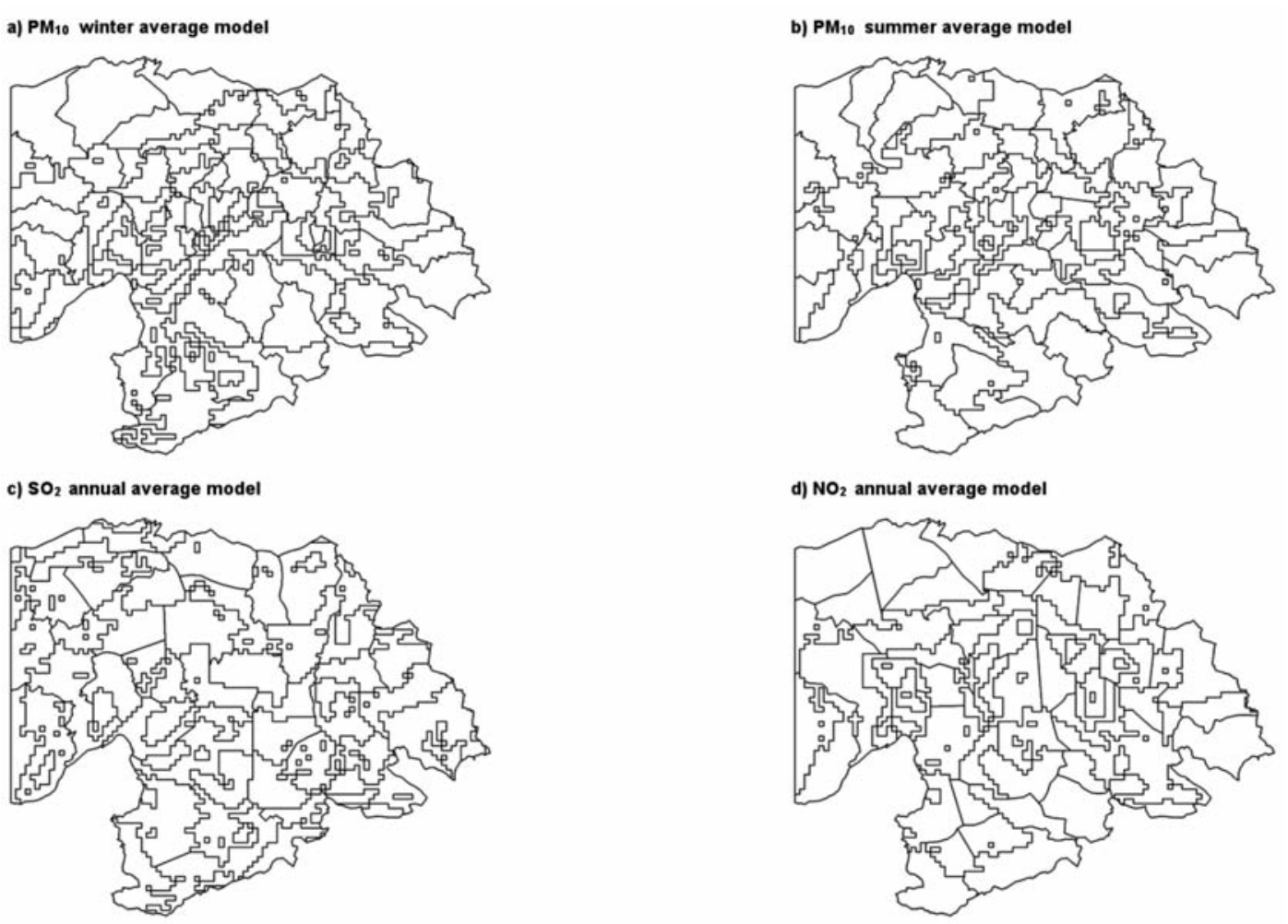

Fig. 5. The resulting four models of small, spatial units in the Zasavje region, Slovenia. 
in the test area were not available. It was originally planned to include the data on emissions from the 18 main sources of air pollution in the region in the study, but consent for the use of emission data could only be obtained for five pollution sources. Importantly however, two of them (the thermal power and the cement plants), are considered the biggest pollution sources in Zasavje, contributed $72.5 \%$ of the emissions of the total amount of suspended particles in $2005 ; 77.3 \%$ of the emissions of $\mathrm{NO}_{2}$ and $91.2 \%$ of $\mathrm{SO}_{2}$ emissions in this region (Cerkvenik et al., 2007).

Secondly, these emission data were available only at the level of the considered nominal emissions at full capacity of devices. The results of modelling would have been significantly more accurate, if the emissions were recorded and reported continuously, Unfortunately, existing legal acts of Slovenia regarding report of emissions to SEA, are vague, e.g. there is no explicit legal rule commanding automatic continuous monitoring. In spite of taking into account less accurate data, we were still able to adequately assess the pollution to develop a methodology of determination of small spatial units. However, for future research, this problem will have to be solved.

Thirdly, detailed emission data on line (traffic) and dispersed pollution sources (individual heating devices and industrial dispersed sources) were not accessible. Currently, in Slovenia, emission values for these sources can only be accessed occasionally on a yearly basis. For a quality assessment of pollution in the area of observation it would be necessary to obtain suitably prepared daily or hourly data (Mlakar et al., 2012). However, the available data were taken into account in the modelling system.

Fourthly, the meteorological data in the form in which they are available in Slovenia today are not the most appropriate for modelling. For quality modelling it is important to use as many measured data of meteorological conditions as possible and models appropriate for the terrain (Grasic, 2008; MEIS Environmental Consulting, 2012). To improve the meteorological part of modelling, real-time measurements of the vertical wind profile, temperature and turbulence in all the valleys in the region of Zasavje should be included. For the description of such a profile, measurements with the "SODAR" system as described by Mlakar et al. (2012) would be more appropriate, but they are currently not permanently available for the region of Zasavje.

Finally, there are also limitation is the modelling process itself. The models of air pollution dispersion are currently even less reliable than the measurement, which in Slovenia is due to the complexity of the terrain and is therefore not representative for a larger area. The value of the models is mostly in the understanding of the situation and results for an entire area (temporal and spatial resolutions) (MEIS Environmental Consulting, 2012). The European Union (EU) directive on ambient air quality and cleaner air for Europe (EC, 2008b) is implementing models to act in parallel to measurements for monitoring air pollution and directly demands the implementation of models as tools that give pollution a spatial image (Grasic, 2008). The modelling system used was chosen based on similar studies (Maheswaran et al., 2005; Choi et al., 2009; Orru et al., 2009; Maheswaran et al., 2012; Mölter, 2012) and the requirements of the forum for air quality modelling (FAIRMODE, 2012).

The air pollution modelling system has been successfully and extensively validated on the site of Zasavje region and in another Slovenian region - the Šoštanj area - of similar topographical and meteorological complexity (Grasic et al., 2008; Boznar et al., 2012; Mlakar et al., 2012, 2013). Due to complexity of validation of air pollution models over complex terrains, additional work has been done in setting up detail validation methodology (Grasic et al., 2011). Secondary pollutants formation is also an important issue. In this study secondary pollutants were taken into account in QualeAria long-range trans-boundary air pollution (QualeAria, 2012). On the small scale of Zasavje region for local emissions the secondary pollutants were not taken into account because it was felt that there was not sufficient time of pollutants to travel from emission sources to the towns and villages of interest and, more importantly, because in the area there are no significant sources of other complementary pollutants needed for formation of secondary pollutants (beside primary emitted $\mathrm{NO}_{2}$ and $\mathrm{SO}_{2}$ ).

The present study offers a starting point for further research in the field of the geospatial health at the population level (linking environmental and health data). Despite the limitations discussed above, the presented study is useful and important for environmental health. It can be said that this kind of research enriches past research in the field in Slovenia and elsewhere (Erzen et al., 2006; Erlih and Erzen, 2010; Kukec et al., 2013).

\section{Conclusion}

A methodology has been established for linking health data with complex meteorology in a highly complex terrain, based on small, spatial units. 
Considering the identified deficiencies, the results generate an important foundation for future studies in the observed area as well as in other areas with a similarly complex terrain.

\section{Acknowledgements}

This study was part of research project V3-1049, which were supported by the Ministry of Health and Slovenian Research Agency, and research projects L1-2082, L1-4154, which was supported by the Slovenian Research Agency. The authors would like to acknowledge all the members of the project group V3-1049: Mirko Bizjak, Rok Fink, Gregor Jereb, Mitja Kosnik, Borut Poljsak and Grisa Mocnik. Additionally, would like to thank the construction material plant Zagorje, the cement plant Trbovlje, the thermal power plant Trbovlje and the glassworks in Hrastnik for providing their emission data.

\section{References}

Beale L, Abellan JJ, Hodgson S, Jarup L, 2008. Methodologic issues and approaches to spatial epidemiology. Environ Health Perspect 116, 1105-1110.

Boznar M, Mlakar P, Grasic B, 2012. Short-term fine resolution WRF forecast data validation in Complex terrain in Slovenia. Int J Environ Pollut 50, 12-21.

Briggs D, Corvalan C, Nurminen M, 1996. Linkage methods for environment and health analysis. General guidelines. Geneva: World Health Organization, 153 pp.

Cerkvenik B, Zabkar R, Podboj A, Persovsek N, 2007. Part of large point sources of emission and their influence on air quality in Zasavje region. Final Report. Energis, 115 pp. (In Slovene).

Choi J, Fuentes M, Reich BJ, 2009. Spatial-temporal association between fine particulate matter and daily mortality. Comput Stat Data Anal 53, 2989-3000.

Desiato F, Finardi S, Brusasca G, Morselli MG, 1998. TRANSALP 1989 experimental campaign - Part I: simulation of 3-D flow with diagnostic wind field models. Atmos Environ 32, 1141-56.

EC, 2008a. 2008/1/EC Directive on integrated pollution prevention and control. Bruxelles: European Council.

EC, 2008b. 2008/50/EC Directive on ambient air quality and cleaner air for Europe. Bruxelles: European Council.

EIONET (European Topic Centre on Spatial Information and Analysis), 2000. Corine Land Cover 2000. Available at: http://sia.eionet.europa.eu/CLC2000/ (accessed on August 2012).

Eitan O, Yuval A, Barchana M, Dubnov J, Linn S, Carmel Y, Broday DM, 2010. Spatial analysis of air pollution and cancer incidence rates in Haifa Bay, Israel. Sci Total Environ 408, 4429-4439.
Elliott P, Cuzick J, English D, Stern R, 1992. Geographical and environmental epidemiology. Methods for small-area studies. New York: Oxford University Press, $382 \mathrm{pp}$.

Elliott P, Wakefield J, Best N, Briggs D, 2000. Spatial epidemiology. Methods and applications. New York: Oxford University Press, 494 pp.

Erlih S, Erzen I, 2010. Assessment of geographical patterns of chronic respiratory diseases in children of Koper municipality. Zdrav Var 49, 19-27. (In Slovene).

Erzen I, Vertacnik G, Podkrajsek D, Juricic M, Ursic A, Zadnik V, Zaletel-Kragelj L, 2006. A study on environmental impact on selected diseases and mortality of population of Zagorje municipality, Final Report. Regional Institute of Public Health Celje, 51 pp. (In Slovene).

ESRI, 2010. ArcGIS. Available at: http://www.arcgis.com/features/ (accessed on July 2010).

FAIRMODE (Forum for Air quality Modelling in Europe), 2012. Available at: http://fairmode.ew.eea.europa.eu/ (accessed on August 2012).

Government of the Republic of Slovenia, 2007. Decree on the emission of substances into the atmosphere from stationary sources of pollution (in Slovene).

Government of the Republic of Slovenia, 2011. Decree on ambient air quality (in Slovene).

Grasic B, 2008. Improvement of the performance of an air pollution dispersion model for use over complex terrain. $\mathrm{PhD}$ thesis, University of Nova Gorica, $175 \mathrm{pp}$.

Grasic B, Boznar M, Mlakar P, Tinarelli G, 2008. Re-evaluation of the Lagrangian particle modelling system on an experimental campaign in complex termin. Nuovo Cimento C 30, 557575.

Grasic B, Mlakar P, Boznar M, 2011. Method for validation of Lagrangian particle air pollution dispersion model based on experimental field data set from complex terrain. In: Advanced air pollution. Nejadkoorki F (ed). Rijeka: In Tech, 535-556 pp.

Hrvatin M, Perko D, 2010. Determination of Slovenia's landforms using method of regional continuous classification. In: Geographic information systems in Slovenia, 2009-2010. Perko D, Zorn M (eds). Ljubljana: Anton Melik Geographical Institute, 21-31 pp.

Jerrett M, Arain A, Kanaroglou P, Beckerman B, Potoglou D, Sahsuvaroglu T, Morrison J, Giovis C, 2005. A review and evaluation of intraurban air pollution exposure models. J Expo Anal Env Epid 15, 185-204.

Kukec A, Farkas J, Erzen I, Zaletel-Kragelj L, 2013. A prevalence study on outdoor air pollution and respiratory diseases in children in Zasavje, Slovenia, as a lever to trigger evidencebased environmental health activities. Arch Hig Rada Toksiko 64, 9-21.

Kukec A, Zaletel-Kragelj L, Bizjak M, Poljsak B, Jereb G, Fink R, Zadnik V, Monik G, Kosnik M, Farkas-Lainsak J, 2012. 
Study of linkage of health and environmental data in Zasavje region as a model study for support in design and implementation of intersectional policies in the field of environment and health. Final Report. Ljubljana: Public Health Centre, 161 pp. (In Slovene).

Maheswaran R, Haining RP, Brindley P, Law J, Pearson T, Fryers PR, Wise S, Campbell MJ, 2005. Outdoor air pollution and stroke in Sheffield, United Kingdom: a small-area level geographical study. Stroke 36, 239-243.

Maheswaran R, Pearson T, Smeeton NC, Beevers SD, Campbell MJ, Wolfe CD, 2012. Outdoor air pollution and incidence of ischemic and hemorrhagic stroke: a small-area level ecological study. Stroke 43, 22-27.

MEIS Environmental Consulting, 2012. Prognostic and diagnostic modelling system for air pollution control in the region (Kooreg). Available at: http://www.kvalitetazraka.si/ zasavje/index.php?lang=en (accessed on August 2012).

Mlakar P, Boznar M, Grasic B, 2012. Zasavje canyon regional online air pollution modelling system in highly complex terrain-description and validation. Int J Environ Pollut 50, 22-30.

Mlakar P, Boznar M, Grasic B, Calori G, 2013. Background air pollution prediction over Slovenia by qualearia modelling system: preliminary validation. In: Proceedings of the 15 th international conference on harmonisation within atmospheric dispersion modelling for regulatory purposes. San Jose R, Perez JL (eds). Madrid: Environmental Software and Modelling Group, Computer Science School, 75-79 pp. Available at: https://docs.google.com/file/d/0B4NKvAPbVkv_X3EyY2xoT FJJdHc/edit (accessed on August 2013).

Mölter AN, 2012. Air pollution exposure and respiratory health in childhood. PhD thesis. University of Manchester, $291 \mathrm{pp.}$

Ocana-Riola R, 2010. Common errors in disease mapping. Geospat Health 4, 139-154.

Orru H, Teinemaa E, Lai T, Tamm T, Kaasik M, Kimmel V, Kangur K, Merisalu E, Forsberg B, 2009. Health impact assessment of particulate pollution in Tallinn using fine spatial resolution and modelling techniques. Environ Health 8, 1-9.
Prüss-Üstun A, Corvalan C, 2006. Preventing disease through healthy environments. Towards an estimate of the environmental burden of disease. Geneva: World Health Organization, 103 pp.

QualeAria (Air Quality Forecasting System), 2012. Available at: http://www.aria-net.eu/QualeAria/index_en.html (accessed on August 2012).

SEA, 2012. List/register of principal to obtain IPPC permission. Available at: http://okolje.arso.gov.si/ippc/tabela/14 (accessed on August 2012).

Segula A, Bolte T, Kolesa T, Komar Z, Murovec M, Muri G, Kranjc I, Groselj D, Cegnar T, Strajhar M et al., 2012. Air quality in Slovenia in the year 2011. Annual Report. Ljubljana: Slovenian Environment Agency, 171 pp. (In Slovene).

SMARS (The Surveying and Mapping Authority of the Republic of Slovenia), 2012. Available at: http://www.gu.gov.si/en/ (accessed on August 2012).

Staut M, 2008. From medical geography to health geography: sub-disciplinary evolution and Slovene perspectives. Geographical Bulletin 80, 79-89. (In Slovene).

Stroh E, Harrie L, Gustafsson S, 2007. A study of spatial resolution in pollution exposure modelling. Int J Health Geogr 6, 1-19.

Tinarelli G, Anfossi D, Bider M, Ferrero E, Trini Casteli S, 2000. A new high performance version of Lagrangian particle dispersion model SPRAY, some case studies. In: Air pollution modelling and its applications XIII. Gryning SE, Batchvarova E, Kluwer (eds). Academic/Plenum Press, 499-507 pp.

Wang XY, Hu W, Tong S, 2009. Long-term exposure to gaseous air pollutants and cardio-respiratory mortality in Brisbane, Australia. Geospat Health 3, 257-263.

Weather Research and Forecasting Model (WRF), 2012. Available at: http://www.wrf-model.org/index.php (accessed on August 2012).

Zadnik V, Reich BJ, 2006. Analysis of the relationship between socioeconomic factors and stomach cancer incidence in Slovenia. Neoplasma 53, 103-110. 